\section{MANTID (INSECTA: MANTODEA) FAUNA OF ORISSA WITH SOME NEW RECORDS FOR THE STATE}

\section{P.M. Sureshan ${ }^{1}$, T. Samanta ${ }^{2}$ and C. Radhakrishnan ${ }^{3}$}

1,2 Estuarine Biological Station, Zoological Survey of India, Gopalpur-on-Sea, Orissa 761002, India

${ }^{3}$ Western Ghats Field Research Station, Zoological Survey of India, Kozhikode, Kerala 673002, India

Email: ${ }^{1}$ samanyu2003@yahoo.com (corresponding author)

Mantids (Insecta: Mantodea) popularly called 'Praying mantids' are predatory insects, actively feeding on a variety of other insects, including other mantids. They play a valuable role in checking the numbers of some insect groups like grasshoppers, moths, flies, aphids, etc., which form their major groups of prey. Despite having rich fauna of mantids, our knowledge on the diversity, variability and biological attributes of Indian mantids is far from satisfactory.

Mukerjee et al. (1995) compiled all the available information on Indian mantids which included 162 species under 68 genera and six families. In recent years, the authors made some attempts to inventorise the mantid fauna of some conservation areas in Maharashtra and elsewhere (Sureshan et al., 2004a,b,c; Sureshan et al., in press a,b). In continuation of such studies collections of mantids were also made from the southern coastal districts of Orissa, which yielded some new distributional records. Most specimens for the present study were collected from the 2-acre campus of ZSI, EBS, Gopalpuron-sea and adjoining places in Ganjam district of Orissa. The collections were mostly made during late evening and night time, by catching adult mantids attracted towards garden and porch lights. Some nymphal stages were also collected, by sweeping with an insect net.

The main collection locality (ZSI, EBS campus) represents a laterite hilly terrain, which lies about $1 \mathrm{~km}$ west of Gopalpuron-sea beach. The area has mixed type of vegetation of various wild grasses; shrubs and cacti intermixed with Neem, acacia, palm and Mango trees.

The specimens were identified following Mukherjee et al. (1995) and the recent classification was followed from Ehrmann (2002). According to Mukherjee et al. (1995) there are 15 species of mantids belonging to 10 genera under three families already reported from Orissa. The present collection is represented by 11 species of mantids pertaining to nine genera and four families out of which seven species are reported for the first time from Orissa. Including the seven species recorded for the first time here, a consolidated list of mantid species now known from Orissa is also provided which includes altogether 22 species ( 14 genera, and 4 families). The material studied is deposited in the collections of ZSI, EBS, Orissa.

\section{Systematic account}

Based upon specimens collected and identified, measurements are in $\mathrm{mm}$. '*' indicates first record from Orissa
Order: Mantodea

Family: Amorphoscelidae

Subfamily: Amorphoselinae

1. Amorphoscelis annulicornis Stål *

1871. Amorphoscelis annulicornis Stål, Ofvers. K. Vetensk Akad.

Forh., 28: 401.

1915. Amorphoscelis indica Giglio-Tos. Bull. Soc. Entomol. Ital., 46: 33.

1956. Amorphoscelis keiseri Beier. Verh. Naturf. Ges. Basel. 67: 33.

Material examined: 1 male; 1 female, EBS Campus, ZSI, Gopalpur-on-Sea, Ganjam district, Orissa, India, 13.viii.2005, (Regn. No. 3937,M), 7.vii.2005 (Regn. No. 3911, F), coll. P.M. Sureshan (under light)

Distribution: India: Assam, Bihar, Daman \& Diu, Himachal Pradesh, Kerala, Meghalaya, Orissa, Tamil Nadu, West Bengal; Sri Lanka.

Measurements: BL: M - 20, F- 20; FW: M - 13.5, F-13.5; PN: $\mathrm{M}-2, \mathrm{~F}-2$.

Diagnostic characters: Body deep brownish, ventral side black. Frontal sclerite narrow, superior edge arched, sinuate on either side. Head with large rounded tubercles. Two tubercles on anterior and posterior border of pronotum, transverse and longitudinal carinae distinct. Mid and hind tarsus with yellow and black rings. Distal segment of cerci racket shaped.

Remarks: The species is reported for the first time from Orissa. It displays darting movement of cerci.

Family: Hymenopodidae

Subfamily: Acromantinae

Tribe: Acromantini

2. Hestiasula brunneriana Saussure *

1871. Hestiasula brunneriana Saussure. Mem. Soc. Phys. Hist. Nat. Geneva, 21: 330.

1927. Hestiasula brunneriana: Giglio-Tos. Das Tierreich, 50: 545.

Material examined: 7 ex. EBS Campus, ZSI, Gopalpur-on-Sea, Ganjam district, Orissa, India, 14.viii.2005 (3941,M), 23.viii.2005 (3944,F), 31.viii.2005 (3946,M), $28 . i x .2005$ (3949,M), 2.x.2005 (395 1,M), 10.x.2005 (3954,M), coll. P.M. Sureshan.

Distribution: India: Andhra Pradesh, Meghalaya, Orissa, West Bengal; Bangladesh and Sri Lanka.

Measurements: BL: M - 21-22, F - 30; FW: M - 18-21, F - 24.5; PN: M - 3-4.5, F - 5 .

Diagnostic characters: Body brownish. Frontal sclerite with the superior margin produced into a blunt angle; inferior border briefly arched and in the middle a faint groove on the surface; superior angle in female with a conical projection and the middle with a long protuberance, bilobed at apex and dotted black. Fore femora brown, folliacious oval, superior edge arched, outer face brown with few black spots, internally three black spots on the superior arch and one on the middle, a little above the spines; four discoidal spines, third one larger; 12 internal spines, entire black, 4 external spines black at tips only. Tibia and tarsi blackish internally. Mid coxae internally black. Fore legs with pale brown in male and dark in female, and its face pale brown in male, and dark brown in female, with few black spots.

Remarks: This species is reported for the first time from Orissa. 
The tubercle of vertex is more elongated in female with tip spatulate. Spots in the forewing of female prominent; colour generally darker in females.

Family: Liturgusidae

Subfamily: Liturgusinae

Tribe: Liturgusini

3. Humbertiella similis Giglio-Tos.

1897. Humbertiella indica Bolivar. Ann. Soc. Entomol. France, 66: 303.

1917. Humbertiella similis Giglio-Tos. Bull. Soc. Entomol. Ital., 48: 83.

1927. Humbertiella similis: Giglio-Tos. Das Tierreich, 50:65.

Material examined: 6 ex. EBS Campus, ZSI, Gopalpur-on-Sea, Ganjam district, Orissa, India, 13.viii.2005 (3938,M; 3939,F), 22.viii.2005 (3943,M), 26.viii.2005 (3945,M), 29.ix.2005 (3950,M), 14.x.2005 (3957,M), coll. P.M. Sureshan.

Distribution: India: Himachal Pradesh, Jammu, Madhya Pradesh, Orissa, Uttar Pradesh; Nepal and Sri Lanka.

Measurements: BL: M - 27-30, F-28; FW: M - 24-27 F - 28; PN: M 5.5-6.5, F 4.

Diagnostic characters: Body colour brownish, wings hyaline (light brown) smoky, longer than abdomen; veins of the wings have brown spots. Eyes rounded. Frontal sclerite brown, superior edge almost straight in the middle. Bossles of pronotum moderately prominent. In foreleg, coxa has black line externally and one black spot near the trochanter, femora externally brown, internally with a black longitudinal line, often divided into two; black patches present on claw groove and inside of first external spine, longer internal spines black at their apical halves only; basal halves deep brown, but blackish only in the distal one or two internal spines only.

Remarks: The species is recorded from Orissa, collected from Padampur of Keonjhar district (Mukerjee et al., 1995). General colour of female lighter. Frontal sclerite dark in males and paler in females.

\section{Family: Mantidae Subfamily: Amelinae \\ Tribe: Amelini \\ 4. Gimantis assamica (Giglio-Tos) *}

1915. Eumantis assamica Giglio-Tos. Bull. Soc. Entomol. Ital., 46: 161. 1927. Eumantis assamica: Giglio-Tos. Das Tierreich, 50: 175.

1995. Eumantis assamica Mukherjee et al., Oriental Ins. 29: 270. 2002. Gimantis assamica (Giglio-Tos) in: Ehrmann, Mantodea, 157.

Material Examined: 2 ex. males. EBS Campus, ZSI, Gopalpuron-Sea, Ganjam district, Orissa, India, 13.viii.2005 (3940), 14.x.2005 (3958), coll. P.M. Sureshan.

Distribution: India: Assam, Orissa, Tamil Nadu.

Measurements: BL: M - 20-21; FW: 19; PN: 4.

Diagnostic characters: Body colour brown, wings hyaline and smoky. Frontal sclerite black, often in the form of band in male. Pronotum short. In fore legs coxae and femora brown with black dots; tibiae triannulated by brownish-black bands and femora brown with black dots; $1^{\text {st }}$ segment of fore tarsi triannulated; others widely blackish near distal parts, femora has four discoidal and four external spines, internal spines are 10. First two external spines very close. Fore wing brown opaque, oval in shape. Abdominal tergum with black band at posterior margin.

Remarks: The species is reported for the first time from Orissa. In India the species is so far only known from Tamil Nadu and Assam. Colour of fore legs yellowish-brown with black dots and bands not prominent in some specimens.

Subfamily: Paramantinae

Tribe: Paramantini

5. Hierodula membranacea Burmeister

1838. Mantis (Hierodula) membranacea Burmeister. Handb. Entomol. 2: 536.

1870. Stagmatoptera veneratoria Saussure. Mitt. Schweiz. Entomol. Ges., 3: 232.

1871. Hierodula membranacea: Saussure. Mem. Phys. Hist. Nat. Soc. Geneva, 21: 84.

1871. Hierodula birivia Stoll. Mem. Mex., 1(4): 89.

Material examined: 1 female, EBS Campus, ZSI, Gopalpuron-Sea, Ganjam district, Orissa, India, 2.viii.2005 (3933), coll. P.M. Sureshan.

Distribution: India: Kerala, Orissa, Tamil Nadu; China; Indonesia; Java and Sri Lanka.

Measurements: BL: F - 84; FW: 50; PN: 32.5.

Diagnostic characters: Body color green. Frontal sclerite higher than wide, upper margin arched. Fore wing green in colour with opaque discoidal area. Pronotum long, gradually narrowed posteriorly and coxal dilation oval, much elongate. In fore legs, coxae with 15-17 spines gradually longer distally; femora with four discoidal spines and four external spines, spines of femora black at tips only.

Remarks: Earlier recorded from Orissa (locality, date and collector details not mentioned). (Mukherjee et al., 1995).

Tribe: Mantini

6. Mantis religiosa inornata Werner *

1930. Mantis inornata Werner. Proc. Zool. Soc. London, 1930: 689. 2002. Mantis religiosa inornata Werner in: Ehrmann, Mantodea, 216

Material examined: 11 ex., EBS Campus, ZSI, Gopalpur-onSea, Ganjam district, Orissa, India, 11.viii.2005 (3934,M; 3935,M), 23.viii.2005 (3964,M), 20.x.2005 (3962,N), 10.xi.2005 (3968,N; 3969,N;3970,N), 13.xi.2005 (3972,F; 3973,M), 15.xi.2005 (3977,N), coll. P.M. Sureshan.

Distribution: India: Maharashtra, Orissa, Uttar Pradesh.

Measurements: BL: M - 59.9, F - 56-72.5; FW: M - 48.9, F - 4150; PN: M - 18.0, F - 18-25.

Diagnostic characters: Body green in colour. Fore wings green, anterior half of costal area reddish-brown and hyaline in discoidal area. Hind wings hyaline. Frontal sclerite with distinct median groove, superior margin arched. Pronotum long, metazoan carinate, with two whitish spots ventrally. In fore legs coxal borders with 6-7 minute spines and few spinules; no callous spots, internal apical lobes divergent; claw groove of femora with yellow patch. Fore femora have four discoidal spines, four external spines and 15 internal spines, black at tips.

Remarks: The species is reported for the first time from Orissa. 
Mukerjee et al., 1995, mentioned about the callous spots on fore coxae internally, but no callous spots are visible in the specimens collected except in one.

\section{Mantis religiosa Linnaeus *}

1758. Gryllus (Mantis) religiosa, Syst. Nat., 10: 426.

1767. Mantis religiosa: Linnaeus, 1767. Syst. Nat., 12(2): 690.

1927. Mantis religiosa: Giglio-Tos, 1927. Das Tierreich, 50: 406.

Material examined: 6 ex. EBS Campus, ZSI, Gopalpur-on-Sea, Ganjam district, Orissa, India, 14.viii.2005 (3942,M), 6.ix.2005 (3947,M), 4.x.2005 (3952,M), 5.x.2005 (3953,M), 10.x.2005 (3955,F), 14.xi.2005 (3979,F), coll. P.M. Sureshan. Distribution: India: Karnataka, Madhya Pradesh, Manipur, Orissa, Uttar Pradesh, West Bengal; Asia; Africa; Australia and Europe.

Measurements: BL: M - 53.9-56, F - 53-70; FW: M - 36-41, F 37-53; PN: M - 15-17, F - 17.9-23.

Diagnostic characters: Body greenish. Fore wings semi-hyaline in female; stigma marked with an elongate, cream coloured spot. Both wings little shorter than body in male. Anterior border of hind wing blackish opaque near apex. Superior margin of frontal sclerite angular with flat carinae, not distinct in smaller specimens. There is a distinct transverse pink line on the vertex, more prominent in the fresh specimens. Costal area of fore wing and lateral borders of pronotum also with pink shades. Prosternum with two small rounded tubercles near base (not very prominent). Metazona carinate. In fore legs, coxae with divergent internal apical lobes; internally with callous spots, absent in some female specimens; a black spot at base which often encloses an oval yellow spot; anterior edge with 6-8 spines and few spinules between them; claw groove of femora yellow, longer internal spines entirely black. Remarks: This species is now recognized to be composed of several subspecies. The present specimen is close to Mantis religiosa religiosa Linnaeus (Ehrmann 2002). The species is reported for the first time from Orissa. It shows aggressive display when disturbed and was found feeding voraciously on other insects, mainly grasshoppers.

\section{Statilia maculata (Thunberg) *}

1784. Mantis maculata Thunberg. Nov. Ins. Spec., 3: 61.

1897. Statilia maculata: Bolivar. Ann. Soc. Entomol. France, 66: 309. 1927. Statilia maculata: Giglio-Tos. Das Tierreich, 50: 410.

Material Examined: 1 ex. female, EBS Campus, ZSI, Gopalpuron-Sea, Ganjam district, Orissa, India, 10.x.2005 (3965), coll. P.M. Sureshan.

Distribution: India: Andhra Pradesh, Arunachal Pradesh, Assam, Bihar, Himachal Pradesh, Madhya Pradesh, Orissa, Sikkim, Tamil Nadu, Uttar Pradesh, West Bengal; Eastern Asia.

Measurements: F: BL: 49.9mm; FW: 33mm; PN: $11.3 \mathrm{~mm}$.

Diagnostic characters: Body brownish, forewing with costal area opaque, discoidal area semi-opaque, smoky. Brownish towards upper margin and tip. Vertex with blackish markings on dorsal surface. Prosternum near coxal joint with black patch. In fore legs, coxae with 6-7 triangular whitish spines and few spinules and also with internal black patch, femora with shining yellow patch, often bordered by a black patch, larger internal spines of femora not entirely black.

Remarks: The species is reported for the first time from Orissa.

Family: Toxoderidae

Sub-family: Toxoderinae

Tribe: Aethalochroaini

9. Aethalocroa ashmoliana (Westwood)

1841. Vates ashmoliana Westwood. Ann. Nat. Hist., 8: 272

1871. Popa (?) ashmoliana: Saussure. Mem. Soc. Phys. Hist. Nat. Geneva, 21: 161.

1877. Arsacia ashmoliana: Stal. Bih. K. Svenska Vetensk Akad. Handl., 4(10): 75 .

1877. Aethalocroa ashmoliana: Wood-Mason. Ann. Nat. Hist., 19(4): 308 .

Material examined: 5 males, EBS Campus, ZSI, Gopalpur-onSea, Ganjam district, Orissa, India, 20.x.2005 (3956), 13.x.2005 (3959), 17.x.2005 (3963), 14.xi.2005 (3976), coll. P.M. Sureshan; Balipada, 2.xii.2005 (3981), coll. B. Dalai.

Distribution: India: Maharashtra, Orissa, West Bengal. Measurements: M: BL: 97-87; FW: 50-45.5; PN: 33-34.

Diagnostic characters: Body brown in colour, Eyes rounded with a small tubercle. Frontal sclerite pentagonal. Forewings smoky, shorter than abdomen, sub-opaque in the upper margin, and distal area hyaline. Hind wings hyaline, upper margin dark brown. In fore legs superior edge of femora little concave. five external spines and eight internal spines. Mid and hind legs short, femora with genicular lobes without spines. Distal segment of cerci wide, round at apex and longer than width. Remarks: Earlier reported from Orissa from Sambalpur District, Deogarh area, collected by A.K. Mondal (Mukherjee et al., 1995).

Tribe: Toxoderopsini

10. Toxoderopsis taurus Wood-Mason.

1889. Toxoderopsis taurus Wood-Mason. J. Asiatic Soc. Bengal, 58: 320. 1927. Toxoderopsis taurus: Giglio-Tos. Das Tierreich, 50: 569.

Material Examined: 2, EBS Campus, ZSI, Gopalpur-on-Sea, Ganjam district, Orissa, India, 14.xi.2005 (3974,F; 3975,M). coll. P.M. Sureshan.

Measurements: BL: M - 89, F - 90; FW: M - 40, F - 42; PN: M - 23.1 F- 24.5.

Diagnostic characters: Body slender, black brown in colour. Frontal process bifid in females, truncated in males. Vertex situated little below level of eyes, with median lobe more elevated than the laterals. Eyes prominent, rounded, with a spine. Pronotum granulate, metazona carinate. In fore legs, coxae blackish internally, at the distal end a lamella like structure is present, serrated and blackish; internally black longitudinal line along the entire length. Internal apical lobes divergent. Femora black, external spines six, internal spines 11, discoidal spines three. Tibiae with four external and sic internal spines. Mid and hind legs have three genicular lobes with long genicular spines. Forewings sub-opaque in the costal region (tip only), distally hyaline. Hind wings hyaline. Cerci 
flat, long 3-crested at tip.

Remarks: Earlier recorded from Orissa (Mukherjee et al., 1995).

Family: Empusidae

Subfamily: Empusinae

Tribe: Empusini

11. Gongylus gongylodes (Linnaeus) *

1758. Gryllus (Mantis) gongylodes Linnaeus. Syst. Nat., 10: 426.

1767. Mantis gongylodes Linnaeus. Syst. Nat., 2(10): 690.

1793. Mantis flabellicornis Fabricius. Entomol. Syst., 2: 16.

1927. Gongylus gongylodes Giglio-Tos. Das Tierreich, 50: 635.

Diagnostic characters: Body greenish-brown. Forewing extending beyond abdomen, wide; costal area abruptly widened at base and brownish opaque; discoidal area hyaline. Hind wing as long as fore wing, hyaline and brownish near apex. Vertex extended. Pronotum long, with rhomboidal expansion. In fore legs, coxae externally with brown bands, internally black, spinules are present externally; spine present near the trochanter. Femora with brown bands, dilated, five external spines, four discoidal spines, all spines black at tip only. In mid and hind legs femora has lobes at the distal end, ventral one is rounded and dorsal lobe is triangular and two in number. Mid abdominal segments laterally folliacious with ventrally transversed black mark.

Measurements: M: BL: (excluding protuberance of vertex) 7375; FW: 45-46; PN: 33-35.

Material Examined: 4 males, EBS Campus, ZSI, Gopalpur-onSea, Ganjam district, Orissa, India, 11.viii.2005 (3936), 28.ix.2005 (3961), 17.x.2005 (3960), 16.xii.2004, Berhampur (3412), coll. P.M. Sureshan.

Distribution: India: Andhra Pradesh, Kerala, Tamil Nadu, West Bengal; Indonesia (Java); Sri Lanka.

Remarks: The species is reported for the first time from Orissa.

The order Mantodea (Insecta) of Orissa is represented by 22 species belonging to 15 genera, nine subfamilies and six families. Among these, family Mantidae is represented by five genera (Heterochaetula, Gimantis, Hierodula, Mantis, Statilia), followed by Hymenopodidae with four genera (Ephestiasula,
Hestiasula, Odontomantis, Creobroter), Empusidae with two genera (Empusa and Gongylus), Toxoderidae with two genera (Aethalocroa and Toxoderopsis), Liturgusidae with one genus (Humbertiella) and Amorphoscelidae with one genus (Amorphoscelis).

In the present study seven species of mantids belonging to six genera are reported for the first time from Orissa, enhancing the number of species and genera already known (15 species and 10 genera) from the state to 22 and 15 respectively. Specimens for the study were collected roughly during a period of one year from December 2004 to November 2005 from the Ganjam district of Orisssa and more precisely from the 2 acre of campus of Zoological Survey of India, Gopalpur and adjoining localities in Berhampur. An analysis of the period of collection reveals that the life history of mantid species of coastal districts of southern Orissa coincides with the onset of southwest monsoon. Most species hatch between July to November and are plentifully available during the months of July-September. Among the species studied adults of Mantis religiosa and Mantis religiosa inornata available in plenty during the months of July-November indicated also by the presence of large number of nymphal stages. These species were also observed actively predating upon other groups of insects mainly grasshoppers and flies during night. The bark dwelling species Amophoscelis annulicornis was available only during the onset of monsoon (July-August) and Aethalocroa ashmoliana only during the post monsoon months (OctoberDecember). Species preferring dense shrubby bushes in plains and hills are mainly represented in the collection. Since most of the specimens were collected during late evening and in the night, and mostly represented by males, it indicates that mantids are positively phototrophic and males are probably mainly attracted towards light.

The study proved that the mantid fauna of Orissa is very rich but not explored fully. Being an active predatory animal group with lot of bio-control potential, mantids form a rewarding group of insects for detailed systematic and biological studies. Even though the present collections were made from a small area, it contains some interesting species, which are being reported for the first time from Orissa. Since most of the districts of Orissa are practically unexplored for the mantid fauna, serious attempts for faunal surveys and field

\section{Table 1. Systematic list of Mantid species known from Orissa.}

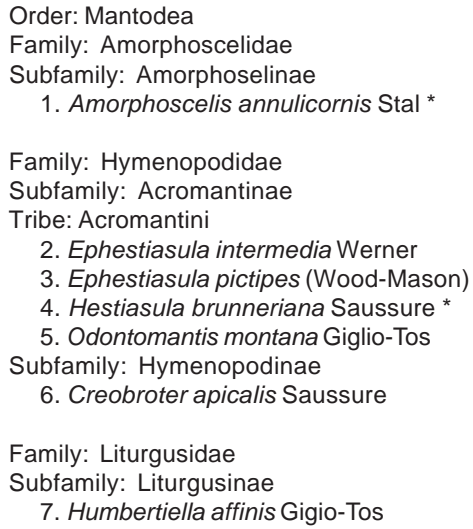

7. Humbertiella affinis Gigio-Tos

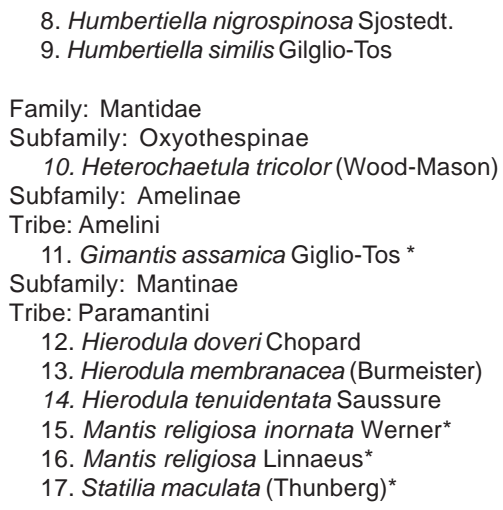

8. Humbertiella nigrospinosa Sjostedt. 9. Humbertiella similis Gilglio-Tos

Family: Mantidae

Subfamily: Oxyothespinae

10. Heterochaetula tricolor (Wood-Mason) Subfamily: Amelinae

Tribe: Amelini

11. Gimantis assamica Giglio-Tos *

Subfamily: Mantinae

Tribe: Paramantini

12. Hierodula doveri Chopard

13. Hierodula membranacea (Burmeister)

14. Hierodula tenuidentata Saussure

15. Mantis religiosa inornata Werner*

16. Mantis religiosa Linnaeus*

17. Statilia maculata (Thunberg)*

\author{
Family: Toxoderidae \\ Subfamily: Toxoderinae \\ Tribe: Aethalochroaini \\ 18. Aethalocroa ashmoliana (Westwood) \\ Tribe: Toxoderopsini \\ 19. Toxoderopsis taurus Wood-Mason. \\ Family: Empusidae \\ Subfamily: Empusinae \\ 20. Empusa guttula (Thunberg) \\ 21. Gongylus gongylodes (Linnaeus)* \\ 22. Gongylus trachelophyllus Burmeister
}


collections of these insects will provide further useful informations on their distribution, endemism, intra-specific variations, bio-control potential etc., from the state.

\section{REFERENCES}

Ehrmann, R. (2002). Mantodea: Gottesanbeterinnen der Welt. Natur and Tier-Verlag, Munster, Germany (Praying Mantids of the world (in German)).

Mukherjee, T.K., A.K. Hazra \& A.K. Ghosh (1995). The mantid fauna of India (Insecta: Mantodea). Oriental Insects 29: 185-358.

Sureshan, P.M., H.V. Ghate \& C. Radhakrishnan (2004a). Statilia nemoralis (Saussure) (Insecta: Mantodea) from Maharashtra. Zoos' Print Journal 19(7): 1550 .

Sureshan, P.M., Md. Jafer Palot \& C. Radhakrishnan (2004b). New additions to the mantid fauna (Insecta: Mantodea) of Andaman and Nicobar Islands, India. Zoos' Print Journal 19(7): 1544.

Sureshan, P.M., H.V. Ghate and C. Radhakrishnan (2004c). Insecta: Mantodea, pp.227-232. In: Fauna of Pench National Park Conservation Area Series 20. Zoological Survey of India.

Sureshan, P.M., H.V. Ghate and C. Radhakrishnan (in press a). Insecta: Mantodea, pp.245-250. In: Fauna of Tadoba Andheri Tiger Reserve, Conservation Area Series No. 25. Zoological Survey of India.

Sureshan, P.M., H.V. Ghate and C. Radhakrishnan (in press b). Insecta: Mantodea. In: Fauna of Sanjay Gandhi National Park. Conservation Area Series. Zoological Survey of India.

\section{Acknowledgement}

The authors are grateful to the Director, Zoological Survey of India, Kolkata and the Officer-in-Charge, Zoological Survey of India, Estuarine Biological Station, Gopalpur-on-Sea for providing facilities and encouragement. We are also grateful to Dr. H.V. Ghate, Professor, Modern college, Pune for critically going through the manuscript and offering useful suggestions.

\section{RE-EMERGENCE OF POLLINATING WASPS (HYMENOPTERA: AGAONIDAE) AFTER NATURAL POLLINATION OF FIGS}

\section{I.P. Abdulrazak ${ }^{1}$ and U.C. Abdurahiman ${ }^{2}$}

\author{
${ }^{1}$ Department of Zoology, Unity Women's College, Manjeri, Kerala \\ 676122, India \\ ${ }^{2}$ Retired Professor of Zoology, University of Calicut, Ulladanchalil, \\ Kozhikode, Kerala 673008, India \\ Email: ${ }^{1}$ razak-ip@rediffmail.com
}

Figs are urn shaped floral receptacles. As female flowers in the fig Syconia reach maturity and their stigma become receptive, pollen loaded female wasps attracted by host specific volatiles enter the fig cavity through the ostiolar bracts. Figs offer larval development sites and mating sites for these pollinators. The Ficus and its pollinator relationship is thus an instance of obligate mutualism (Galil \& Eisikowitch, 1971; Wiebes, 1979; Joseph \& Abdurahiman, 1984). Because of the closed structure of the fig, the pollinating wasps (= foundresses) are supposed to always die within the fig cavity after pollination (Hill, 1967; Galil \& Eisikowitch, 1969; Bronstein, 1988). However, Grandi (1920) in his monograph on the pollinator of common fig Ficus carica, clearly stated that the pollinator, Blastophaga psenes L. may exit the figs they have entered. In this study on three fig species, we examined the incidence of the escape of foundresses from the figs after pollination, in order to ascertain whether this event occurs uniformly in all the three species.

\section{Materials and methods:}

The required data were collected from three most accessible Ficus species in Kozhikode and Malappuram districts of Kerala. Two species of monoecious figs, namely, Ficus racemosa and F. drupacea pollinated respectively by Ceratosolen fusciceps Mayr and Eupristina belgaumensis Joseph; and one dioecious species, Ficus hispida, pollinated by Ceratosolen solmsi marchali Mayr were selected for this study. For each species, figs were collected ten days after natural pollination had occurred. Owing to differences in phenology of the different fig species, they were studied at different times of the year with different sample sizes. Naturally pollinated figs were dissected under stereomicroscope. Foundresses were recorded as being found either inside the fig cavity or stuck in the ostiole. In the latter case, the position of the head which are orientated towards the ostiole outlet or directed towards the internal cavity of the fig, was also recorded. When no foundresses were found inside a fig, other traits were recorded that demonstrated whether or not the fig had been entered by one or more foundresses, i.e., the presence or absence of wings left on the fig's surface at the edge of ostiolar scales, tanning of the styles caused by injury from insertion of the ovipositor, and enlargement of the ovaries. Evidence of entry combined with the absence of a foundress indicate that foundress do exit from the figs. 